\title{
－特集 家族社会学の回顧と展望一1970年代以降
}

\section{コメント 2 新しいパラダイムの課題}

\section{落合恵美子}

Key words : パラダイム転換、個人、ネットワーク

1 .

森岡先生の総括に感服した。これまでわたしたち若い世代は、先行世代の代表者としての森岡先生の 胸を借りて批判を展開してきたのだが、今日、森岡先生は当の「核家族パラダイム」の成立過程を当事 者として語ってくださったばかりか、それを乗りこえる新しいパラダイムの提案までご自身でなさって しまった。これではもうわたしが申すべきことは何もないようなものだ。

シンポジウムの後で、「森岡先生は新しいパラダイムなど提案されるべきではなかった。先生には核 家族パラダイムを貫いていただきたい」という感想を聞いた。わからない感想ではないが、やはり今回 のなさりょうのほうが森岡先生らしかったとわたしは思う。

私的な思い出話のようになって恐縮だが、1986年に六甲山で開かれた第19回家族社会学セミナーで、 まだ大学院生であったわたしが食事も喉を通らないほど緊張しながら初めて集団論的パラダイム批判を 行なったとき、当時のわたしにしたら予想外のことに、森岡先生は初めからわたしの話に理解を示して くださった。厳しい叱責や反論ももちろんたくさんいただいたので、先生の御寛容と励ましは筆舌に尽 くせぬほど有難かった。

今回の御報告の中で森岡先生は、御自身が若い世代として、先達の「家パラダイム」では立ち向かえ ない戦後の家族変動を解明するために「核家族パラダイム」を確立していった経緯を語られた。そのお 話をうかがいながら、先生の寛容さに更めて合点がいったような気がした。パラダイム転換というのは、 誰よりも森岡先生ご自身が進めていらしたことだった。変わりゆく現実を把握するためには理論を变え ねばならぬこともある、という30数年前と変わらぬ姿勢を、先生は示して下さったのである。

先生は、パラダイム転換ばかりではなく、新たなパラダイムの確立にも精力を傾けてこられた。「新 しいパラダイムを自覚的に鍛練した」と自負される先生が、核家族パラダイムの批判者たちが新しい家 族定義すら未だ明示しないことを、歯がゆく思っていらしたことはよくわかる(1)。それが今回のご提案 につながったと思うと面目ないが、これについては少しばかり言い訳もある。80年代の若い世代からの 批判には、研究者が「普遍的」な家族定義を与える研究法自体への批判が含まれていた。広い意味での 構築主義的志向と言おうか。普遍的家族定義はそもそも必要ないし可能でもない、というのである。

したがって、家族を個人のネットワークととらえるご提案にはわたしも賛同するが、「高密度」とか 「サポート」とかいった限定まで付けるのは、率直に言って研究者の主観の入りすぎではないかと感じ る。個人の広げるネットワークのうちある部分を、研究目的に応じて、機能的、当事者の主観的、ある 
いは当該社会の規範的基準で区切って「家族」と定義するので十分なのではなかろうか。

新しいパラダイムの姿は、森岡先生のおっしゃるほど茫漠としているわけではない。その輪郭はすで に見えているし、自覚的にその立場に立つ研究もすでに多くの成果を挙げてきている。今回のシンポジ ウムで報告された 5 分野のレヴュこそが、その何よりの証拠である。以下では 5 本の報告を検討する が、各分野別の論点に深入りするかわり、複数の報告が取り上げた共通の論点を見ることで、新しいパ ラダイムの方向性を浮かび上がらせたい。（以下敬称略）

2 .

まず大きな理論的枠組みとしては、集団論的パラダイム（あるは核家族パラダイム、近代家族パラダ イム）から個人の織りなすネットワークとしての家族モデルへ、という、まさに森岡が示したようなパ ラダイム転換がこの約30年間に起きた、という見方がほとんどの論者により打ち出された。「集団モデ ルから個人モデルへ」(清水)、「『集団としての家族』という視角と『個』という視角」(下夷)、「個人 単位の視角」(山根) と、そのものずばりの表現も報告の中に再三登場した。

「個人のネットワーク」という表現では、正確に言うと二つのことが意味されている。集団からネッ トワークへという家族観の転換と、家族単位から個人単位へという社会の基礎単位の捉え方の転換であ る。後者では、個人がすべて家族に属しているわけではないし、個人が取り結ぶ家族もさまざまであり うるということも含意されていると言ってよかろう。清水の言を借りれば、「現実には他の社会システ ムとの関係からモーダルパターンというものがあるにせよ、多様なマイノリティが混在することが常態 的とみなされる。」

しかし、パラダイム転換の性格は、集団から個人へ、という一言で表わせるものではない。この視角 だけでは覆いきれない側面からパラダイム転換を描き出したのが、制度論・変動論を扱った牟田報告で ある。牟田は、1960年代以来の「家族社会学の自律化・体系化は、一種の自閉化を伴うプロセスでもあっ た」と指摘する。「家族を閉鎖的集団としてとらえがち」で、そのミクロな内部関係に焦点をあてる一 方、「歴史的・構造的関心が薄れて」それまでの日本の家族社会学の伝統であった制度論・変動論的研 究が退潮したと言うのである。その制度論・変動論への関心が復活したのが、この領域にとってのパラ ダイム転換であった。

個人への着目と制度・変動への関心と言うと、一見別のことのようだが、これらはいずれも近代家族 モデルからの脱却である点が共通している。すなわち前者は集団性、後者は家内領域と公共領域の分離 という近代家族の基本的前提がゆらぎだしたことに対応する。また、山根報告は、ジェンダー研究が 「主婦役割、母役割、セクシュアリティ」といった性別役割のみならず、「家族の単位性、情緒性、核 家族モデルも相対化した」とまとめているが、これはすなわち近代家族モデルの相対化である。集団論 的パラダイムが近代家族的家族観を背後仮説として取り込んで成り立っていたのと同じように、新しい パラダイムは近代家族を相対化する家族観に支えられている。このことを牟田は、近代家族論の「イデ オロギー性」と指摘した。「イデオロギー性」という表現を否定的にとる必要はない。パラダイムとい うものは、そもそも明示的な家族定義には還元できない、背後仮説や価值評価の全体的セットとしてし かありえないのだから。 
では、新しいパラダイムはどのような背後仮説（あるいは原初想定）のセットなのだろうか。 5 本の レウュー論文を参考にしながら、試みに整理してみたのが以下である。

(1) 社会の基礎単位は家族ではなく個人である。

(2) 家族は個人のネットワークである。

（3）個人の取り結ぶ家族のありかたは多様であり、家族に属しない個人もいる。

(4) 家族は社会に埋め込まれており、他の社会制度とつねに連動している。

(5) 家族制度は社会によって異なり、歴史的に変化する。

(6) 家族成員間の情緒的絆は、つねに強いとは限らないし、特に価値づけられるべきでもない。

(7) 家族成員は性別により、つねに異なる役割を果たすわけではない。

(8) 家族の基本型は核家族であるとは言えない。

3 .

ではこうした理論的転換は、家族社会学の大きな潮流を形作っている問題解決志向的研究にとって、 いかなる意味を持ったのだろうか。家族問題・家族病理についての清水報告、家族福祉政策についての 下夷報告では、この問いが一つの焦点とされた。清水がまとめているように、「家族病理学の一時代」 と言われた1970年代から、80年代以降の「転換期」を経て、90年代の退潮期へという流れは、集団論的 パラダイムの隆盛とそこからの脱出の過程に密接に関連している。清水は「転換」を家族問題研究のノ一 マライゼイション（一般汎化）と位置づけ、「病理モデルから生理対処モデルへ」の転換と、「集団モデ ルから個人モデルへ」の転換の二点をその内容として挙げた。人はみな同じような家族に属していると いう前提の集団論的モデルでは、例外的な一部の家族や個人の「病理」や「逸脱」と見えたものが、む しろオルタナティブな選択的ライフスタイルと見なすべきであるとか、人生上のタイミングなどによっ て誰もが直面する可能性がある状況であるとかと、捉え直されるようになったのである。問題解決志向 的研究においても、パラダイム転換の意味は大きかった。

下夷も、80年代後半の「近代家族を基底におく家族福祉政策モデル」と、90年代の「個人を基底にお く家族福祉政策モデル」とを区別している。ただし下夷は「近代家族型から個人型へと一方向的に転換 するのではなく、それぞれが機能する状況と機能しない状況を整理し、双方が混在する形で展開してい くことになろう」とする。「家族福祉政策の想定する個人は、決して原子的な個人ではなく、家族の中 で生活している個人であ」るからと言う。

下夷の提案は穏健で現実的に見えるかもしれないが、わたしはいささか疑問を感じる。「家族の中で 生活している個人」という想定では、うまくいかないことがわかってきたからこそ、個人を単位とする パラダイムが出てきたのではなかったか。モデルとかパラダイムというものは、折東や場合による使い 分けより、一つの立場を徹底したらどうなるかを突き詰めてみたほうがよいように思う。下夷は現実に 家族が果たしている役割をきちんと見たいと思っているのだろうが、それは個人を単位とするモデルで も可能なはずである。個人の広げているネットワークの中で、その一部である「家族」が果たす役割を、 家族以外の者がその役割を果たす場合も考虑に入れつつ論じればよい。しかしその逆、家族を単位とす るモデルで個人を扱うのは、分析的に難しかろう。 
「個人単位の福祉」という考え方は、徹底すれば、相当ラディカルな思想的転回を要求する。社会学 のレビューには残念ながら含まれないのかもしれないが、労働経済学者伊田広行の『性差別と資本制』 （本誌第 8 号に書評掲載）での論には学ぶところが多い。伊田は公的補助を、介護している家族にでは なく、高齢者や障害者本人に渡すべきだと主張する。それによってヘルパーを雇うのか、ケアしてくれ た家族に支払うのかは、本人が自己決定すべきだと言うのである。これに対し、家族を福祉の単位とし て家族に公的補助を渡すのでは、福祉の当事者である個人は、家族への依存から抜け出すことができな い。逆説的に聞こえるかもしれないが、家族からの解放は弱者にこそ切実である。日本で高齢女性の自 殺率が高いのは、家族への負い目のためなのかもしれない。「近代家族を基底におく家族福祉政策モデ ル」あるいは「家族福祉」という概念自体が、家族の中の弱者を抑圧する装置になっているのではない かという可能性を含め、徹底して考え直す必要があると思う。

4 .

家族制度・家族変動を論じた牟田報告では「家族社会学の自閉への自省」という論点が出された。牟 田が「自閉」という言葉で表現していることには、二つの側面があろう。対象としての家族領域への自 閉と、専門としての家族社会学への自閉すなわち学際性の欠如である。近代家族的な公私の分離という 集団論的パラダイムの前提が、こうした㷌結をもたらしたことは既に論じた。

では、パラダイム転換を経た現在の日本の家族社会学は、これらの点を克服したのだろうか。山根報 告は、ジェンダー研究を概観しての第 3 の特徵として、「家族の内部構造分析にとどまらず、家族を家 族外ネットワーク、市場、国家などとの関連において分析」する視角の登場と深化を挙げている。企業 社会や法制度との関連や、家族を超えたネットワークを扱った研究などがその例とされる。「家族と外 部システムとの相互関係」という従来の枠組とはやや異なる把握のしかたが必要だと森岡は言うが、山 根の挙げるこれらの研究にはそうした方向性も芽生えている。個人の広げるネットワークのある部分が 家族であって、それ以外のネットワークと関連しながら機能しているというイメージと言おうか。

家族以外の諸制度を視野に入れた研究の展開は、他の報告者からも示された。福祉政策を論じた下夷 は、「国家一家族一個人」の関係を軸に報告を構成した。制度論・変動論の分野では、牟田自身が国家 との関わりで日本の家族史研究を進めている。

他の社会制度との関係も視野に入れたマクロな家族研究を実りあるものにするには、比較の視点を持 つことが有効だと思われる。例えば企業と家族の関係を見ようとしても、通りいっぺんの洞察を超える のは容易ではない。しかし日本のケースを別の国のケースと比較してみれば、「日本的経営」の効果を 特定できるというように。

「日本」という問題設定は、やはり複数の報告に見られた。家族史研究の「日本の文脈へ」の展開

(牟田)、「日本型の福祉体制の探求」(下夷) などである。牟田は「この潮流は、われわれがこれまで のような知の輸入消化に終わるのでなく、日本の家族史研究によって、国際的に貢献しうる可能性を示 している」と高らかに宣言しているが、家族社会学の多くの分野での本格的な国際比較研究は、まさに これからの課題である。例えば「日本的経営」や「日本型福祉」、「イエ社会」は本当に日本独特なの かといった問い直しを含め、次の10年で飛躍的な成果が上げられるのではなかろうか。 
5 .

最後に渡邊報告に関連して、人口学と家族社会学との関係について考えておきたい。渡邊報告は、家 族研究者が必ず踏まえておくべき、重要な人口学的情報を満載していた。なかでも、まだほとんど公表 されていない生存直系尊属数のシミュレーション結果は、たいへん貴重なものである。

しかし、渡邊報告を聞いて、わたしは一つの感溉を持った。それは、人口学と家族社会学との対話は まだ難しいのかな、ということである。研究史を振り返れば、戸田貞三以来、小山隆、森岡清美に至る まで、家族社会学は人口学とむしろ密接な関連を持ちながら発展してきた。それが切れてしまったのは 何故なのかと、セッションのあと森岡先生にお尋ねしたところ、人口学の精緻化が他分野の研究者の参 入を著しく難しくしてしまった、とのことであった。1960、70年代に専門化し自閉化する道をたどった のは、家族社会学だけではなかった。1980年代後半以降、人口学者の家族問題研究会等への積極的な参 加を得て、絆は復活しつつあるかと見えたのだが、なかなかそう簡単ではないらしい。

とはいえ、家族社会学の側から見れば、人口学から学べることはたくさんある。他の場所でも再三述 べたが、伊藤達也の人口学的世代論の家族研究にとっての含意は計り知れない［伊藤, 1994]。また核 家族化の有無や程度を論じるとき、同居可能率と同居実現率とを区別する廣嶋清志の分析法に拠らずに 済ますことは、もはや出来ない [廣嶋, $1984 ； 1993$ ]。日本国内の地域差や歴史的変化をマクロ視点か ら把握するには、清水浩昭や伊藤達也のように人口統計により大勢をつかむ方法が有効である [清水, 1992 ; 伊藤, 1990]。また、いささか手前味噌になるが、歴史人口学的方法による近世家族の実証分析 は「家」研究に新たな視角を付け加えつつある [速水, 1997 ; 落合, 1997a ]。さらに言うと、家族社 会学のパラダイム転換についても、その背後にある家族変動は、人口学的変化と密接に関係していると わたしは考えている [落合, 1997b]。人口学と家族社会学との連携の復活は緊急の課題である。

\section{注}

（1）ただし近代家族の定義については精緻な論争がある [西川, 1996 ；牟田，1996；落合，1996］。

\section{考支献}

速水融, 1997, 『歴史人口学の世界』, 岩波書店.

廣嶋清志, 1984,「戦後日本における親と子の同居率の人口学的実証分析」, 『人口問題研究』169, 31 -42 .

廣嶋清志, 1993,「若年有配偶男子の世帯形成動向」, 『人口学研究』16, $1-16$.

伊田広行，1995，『性差別と資本制』，啓文社.

伊藤達也，1990，『世帯構成とその地域性』，昭和60年国勢調査モノグラフシリーズ 9.

伊藤達也, 1994, 『生活の中の人口学』, 古今書院.

牟田和恵, 1996,「日本型近代家族の成立と陥穷」, 井上俊他編『〈家族〉の社会学』, 岩波書店, 55 -74 .

西川祐子, 1996, 「近代国家と家族」，井上他編上掲書, 75-99.

落合恵美子, 1996,「近代家族をめぐる言説」, 井上他編上掲書, 23-53. 
落合恵美子, $1997 \mathrm{a}$,「失われた家族を求めて」, 河合隼雄他編『家族と性』, 岩波書店, 35-57.

落合恵美子, $1997 \mathrm{~b}$, 『21世紀家族へ（新版）』，有斐閣.

清水浩昭, 1992,『高路化社会と家族構造の地域性』, 時潮社.

（おちあい えみこ・国際日本文化研究センター） 


\section{Comment 1 : Toward a Paradigm Shift in Family Sociology}

Kiyomi Morioka

Key words : nuclear family paradigm, IE paradigm, high-density network paradigm

With the understanding that one significant purpose of the present symposium is to identify any newly emerging paradigms in the field of family sociology in Japan, I focus my discussion on the issue of paradigm shift rather than on each of the excellent papers presented in this symposium.

The paradigm which has been dominant so far may be called the 'nuclear family paradigm.' It was established in the middle of the 1960' $\mathrm{s}$ through the so-called nuclear family controversy, replacing the IE paradig $m$ which failed to interpret and analyze the drastic changes in the family in the post-war period.

In response to recent family changes since around 1970, family sociologists have tried earnestly to build up a new paradigm, but they have not been successful enough in that attempt. I deem a few minor paradigms emerging instead of a major one, and want to propose a high-density network paradigm as one of the minor paradigms of great promise.

\section{Comment 2 : Issues for a New Paradigm of Japanese Family Sociology}

\section{Emiko Ochiai}

Key words : paradigm shift, individual, network

The paradigm shift to view the family as a network of individuals, instead of viewing it as a group, has been the most fundamental change in Japanese family sociology since 1980 . Sharing this point, the authors of the papers in this special issue discuss further points; the applicability of the new paradigm to the analysis of family problems, the method to go beyond family studies including the state and the company, and frameworks to deal with the "Japanese family". Reestablishing the link between demography and family studies is another urgent issue. 